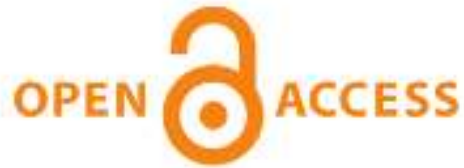

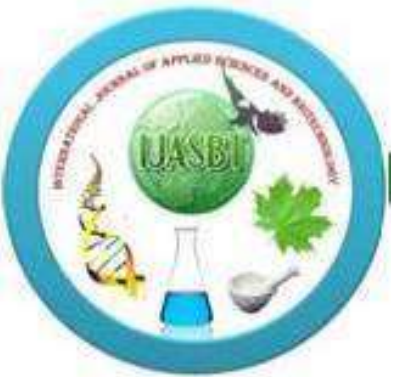 \\ International Journal of Applied Sciences and Biotechnology
}

\author{
A Rapid Publishing Journal
}

ISSN 2091-2609

\section{Indexing and Abstracting}

CrossRef, Google Scholar, Global Impact Factor, Genamics, Index Copernicus, Directory of Open Access Journals, WorldCat, Electronic Journals Library (EZB), Universitätsbibliothek Leipzig, Hamburg University, UTS (University of Technology, Sydney): Library, International Society of Universal Research in Sciences (EyeSource), Journal Seeker, WZB, Socolar, BioRes, Indian Science, Jadoun Science, JourInformatics, Journal Directory, JournalTOCs, Academic Journals Database, Journal Quality Evaluation Report, PDOAJ, Science Central, Journal Impact Factor, NewJour, Open Science Directory, Directory of Research Journals Indexing, Open Access Library, International Impact Factor Services, SciSeek, Cabell's Directories, Scientific Indexing Services, CiteFactor, UniSA Library, InfoBase Index, Infomine, Getinfo, Open Academic Journals Index, HINARI, etc.

CODEN (Chemical Abstract Services, USA): IJASKD

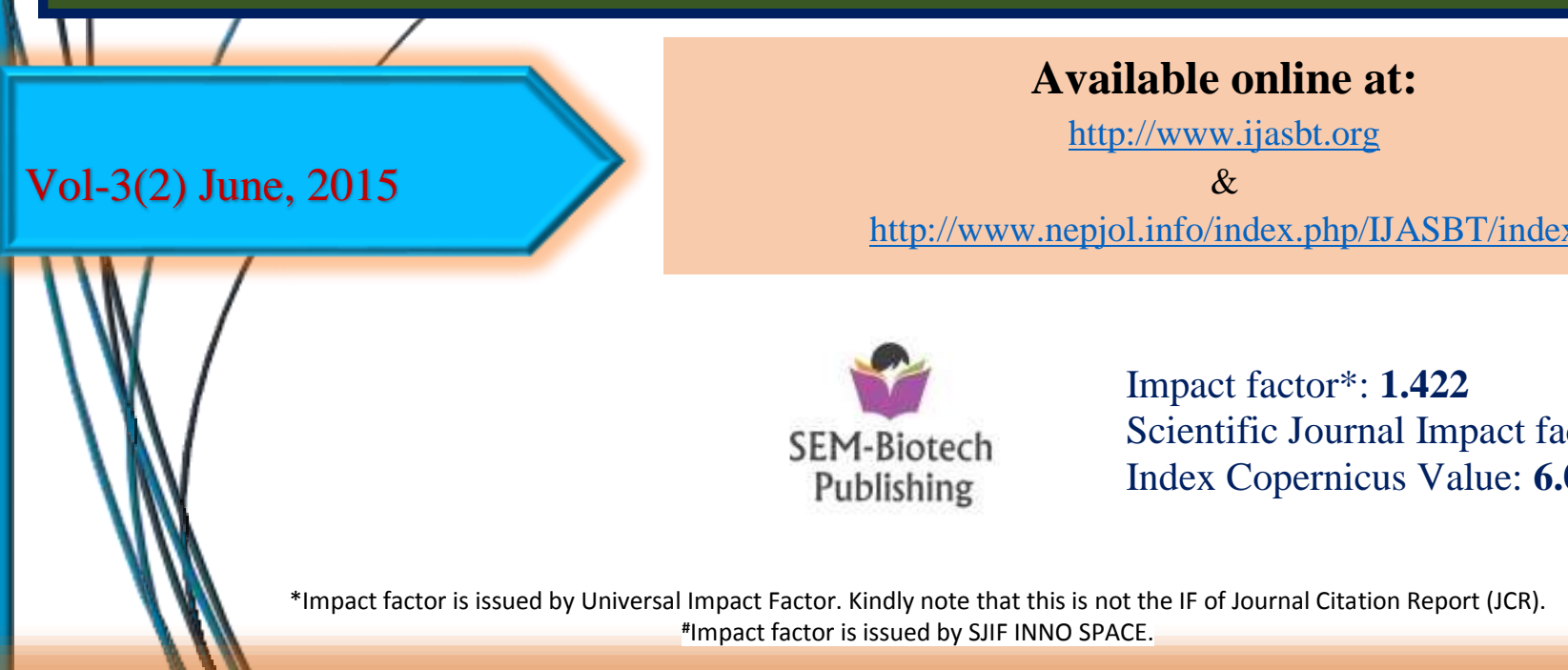

For any type of query and/or feedback don’t hesitate to email us at: editor.ijasbt@gmail.com 


\title{
ISOLATION, SCREENING AND OPTIMIZATION OF ESTUARY REGION (KHAMBHAT, GUJARAT) MICROALGAE FOR LIPID/OIL PRODUCTION
}

\author{
Mahendraperumal Guruvaiah*, Madhuri Narra, Garima Dixit, Punit Karawadia and Deval Shah
}

*Sardar Patel Renewable Energy Research Institute, Post Box No. 2, Vallabh Vidyanagar - 388 120, Anand, Gujarat, India.

Corresponding author email: Mahendraperumal@gmail.com

\begin{abstract}
Water and soil samples were collected from gulf of Khambhat region, Gujarat. The cations and anions like calcium, chloride, fluoride, magnesium, sulphate and total hardness as calcium carbonate were analyzed. Collected estuarine samples were cultured in three different media under standard laboratory conditions. These enrichments were then used to isolate pure unialgal culture by conventional method. Thirty four isolates belonging to twelve species of Cyanobacteria, twenty species of Chlorophyta and two taxa of Bacillariophyta were identified and are maintained at SPRERI centre. The Chlorophyta were found better accumulators of lipids than the cyanobacterial species. Five promising strains (SBC 7, SBC 9, SBC 17, SBC 18 and SBC 19) have been selected. In-house isolates SBC19 and SBC 17 showed highest acetyl CoA carboxylase (ACCase) of $55.2(\mathrm{U} / \mathrm{ml})$ and $51.2(\mathrm{U} / \mathrm{ml})$ respectively, with $0.375 \mathrm{~g} 1-1$ nitrogen concentration in 24 days. Biomass production was highest for $2.4 \mathrm{~g} / \mathrm{l}$, (SBC 19) and $2.7 \mathrm{~g} / \mathrm{l}$ (SBC 17) with $1.5 \mathrm{~g} 1-1$ nitrogen concentration. The highest lipid content was $52 \%$ and $48 \%$ in SBC19 and SBC 17, respectively, with 0.375 g 1-1 nitrogen concentration of solvent extraction method. Lipid accumulation was found enhanced by more than $50 \%$ on dry mass basis under nitrogen starvation.
\end{abstract}

Keywords: Microalgae; Biomass; Acetyl CoA Carboxylase; Lipid

\section{Introduction}

The depletion of fossil fuel reserves has caused an increase price of diesel fuel. The uncertainty in their availability is considered to be the important trigger for researchers to search for alternative sources of energy, which can supplement or replace fossil fuels (Harun et al., 2010; Mata et al., 2010). In recent years, researches are busy exploring alternate fuels from various biological renewable sources. Biodiesel is an alternate to diesel fuel, which is produced from oils via transesterification. It is non-toxic, biodegradable and has the potential to replace the conventional diesel fuel. The use of biodiesel will ultimately leads to reduction of harmful emissions of carbon monoxide, hydrocarbons and particulate matter and to the elimination of SOx emissions, which can also help in reducing the greenhouse effects and global warming. Presently, biodiesel is produced from different crops, such as, soybean, rapeseed, sunflower, palm, coconut, jatropha, karanja, used fried oil and animal fats (Khan et al., 2009). There is a limitation in use of these oils as alternate fuels because of its food demand, life span, lower yield/ha, higher land usage and higher price inter alia (Mata et al., 2010). It is therefore necessary to search for non-food alternate feedstocks for biodiesel production. Selection of biodiesel feedstock is based on higher yields, short duration, lower production cost and less land usage. Among various biodiesel feedstocks, the microalgae oil has potential to replace the conventional diesel fuel. Microalgae are desirable for biofuels production as compared to plants because (1) microalgae have fast growth rates, high biomass yield potential using non-fresh water streams as substrate, (2) microalgal based biofuels do not interfere with food security concerns, (3) biofuels generated from microalgal lipids have less emissions and contaminants as compared to petroleum based fuels, therefore, reduced greenhouse gas emissions, and (4) microalgae require non-arable land for their cultivation, can utilize industrial flue gas as carbon source and can be harvested daily (Chisti, 2007). The main objective of this research paper is to focusing on isolation, screening and optimization of microalgae cultivation in laboratory level with the main aim of producing biofuels.

\section{Materials and Methods}

\section{Media and Nutrients used for the growth studies}

Water and soil samples were collected by random sampling method from gulf of Khambhat region, Gujarat. The analyses of cations and anions like (calcium, chloride, fluoride, magnesium, sulphate and total hardness as $\mathrm{CaCO}_{3}$ ) were done by Vaibhav Analytical Services, using established protocols. Collected samples were observed under light microscope used for observing and images were captured with RADICAL RxLR-3 microscope fitted with 
camera and photomicrographic system. The identification was done using keys in standard monographs (Desikachary, 1959; Philipose, 1967; Iyengar and Desikachary, 1981). After observation, samples were enriched in different modified media, Bold's Basal medium (Starr and Zeikus, 1993) at pH 6.6, BG11 medium (Rippka et al., 1979) at pH 7.5, Chu 13 medium (Chu, 1942) at $\mathrm{pH} 7.4$ and $\mathrm{F} / 2$ medium (Guillard and Ryther 1962) at $\mathrm{pH} 8.2$ followed by plating and incubated under standard temperature condition of about $25 \pm 2{ }^{\circ} \mathrm{C}$ under a photoperiod of $12: 12 \mathrm{~h}$ light dark cycle at light intensity of $35 \mu \mathrm{mol}$ photon $\mathrm{m}^{-2} \mathrm{~s}^{-1}$. The microalgae were isolated and purified through serial dilution followed by plating and regular observation under microscope.

The biomass of the entire cultures was measured by weighing dried sample of the culture suspensions. Filter papers (Whatman GF/C $0.7 \mu \mathrm{m}, 47 \mathrm{~mm}$ in diameter) stored in a constant room temperature $\left(23 \pm 2^{\circ} \mathrm{C}\right)$ were preweighed. Then, samples of $5 \mathrm{ml}$ of each alga culture were filtered through the filter papers. They were dried over night at $110^{\circ} \mathrm{C}$ and then weighed again at room temperature. The biomass content was calculated.

\section{Preparation of sample for the determine the acetyl-CoA activities}

Algae cells were added to an assay mixture containing acetyl-CoA, bicarbonate, magnesium and ATP, and aliquots were removed at set time points and stopped by the addition of trifluoroacetic acid. The level of acetyl-CoA remaining in each aliquot was determined via a citrate synthase assay, in which the formation of the yellow compound dithiobisnitrobenzoic acid-thiophenolate was followed spectrophotometrically at $412 \mathrm{~nm}$.

$25 \mathrm{ml}$ of algae cells were harvested by centrifugation $(8000$ $\mathrm{x} \mathrm{g}, 4^{\circ} \mathrm{C}, 10 \mathrm{~min}$ ), collect the pellet and dissolve in ice- cold $100 \mathrm{mM} \mathrm{KPO} 4$ buffer solution (pH 7.5). The algae suspension were kept under sonication for $15 \mathrm{~min}$, (in ice bath, $20 \mathrm{~Hz}, 30 \%$ Amp) condition. Then again centrifuge the algae suspension $\left(8000 \mathrm{x} \mathrm{g}, 4^{\circ} \mathrm{C}, 10 \mathrm{~min}\right)$. Finally the supernatant was used for enzyme assay. Acetyl-CoA carboxylase activity was measured using a discontinuous spectrophotometric assay used as Laura Willis et al., 2008 method.

\section{Determination of lipid content by Nile red and solvent extraction methods}

Nile red (9-(Diethylamino)-5H benzo [ $\infty$ ] phenoxazin-5one) has been shown to be quite useful in detecting neutral lipids in many different microalgae. The use of the Synergy ${ }^{\mathrm{TM}} \mathrm{H} 4$ Multi-Mode Microplate Reader to monitor the high levels of lipid in algal strains using fluorescence. After successful isolation, the microalgae were screened for their lipid accumulation using above method (Fig. 1.) Another method was used as solvents - lipid extraction method. Freeze-dried algal mass was extracted with methanol containing 10\% DMSO according to Chiara et al., (2002) but with slight modification. The solvent with the biomass was heated at $45^{\circ} \mathrm{C}$ and stirred for 45 minutes and the mixture was centrifuged at $3000 \mathrm{rpm}$ for $10 \mathrm{~min}$. The supernatant removed and the pellet was re-extracted with a mixture of diethyl ether and hexane $(1: 1 \mathrm{v} / \mathrm{v})$. Added equal volume of water to the solvent mixture and supernatants so as to form a ratio of 1:1 (v/v). The mixture was centrifuged again and the upper phase was collected. The water phase was re-extracted and the organic phases that contain total lipid were combined and evaporated to dryness under nitrogen protection. Thereafter, the total lipids were measured gravimetrically after freeze drying for $24 \mathrm{~h}$.
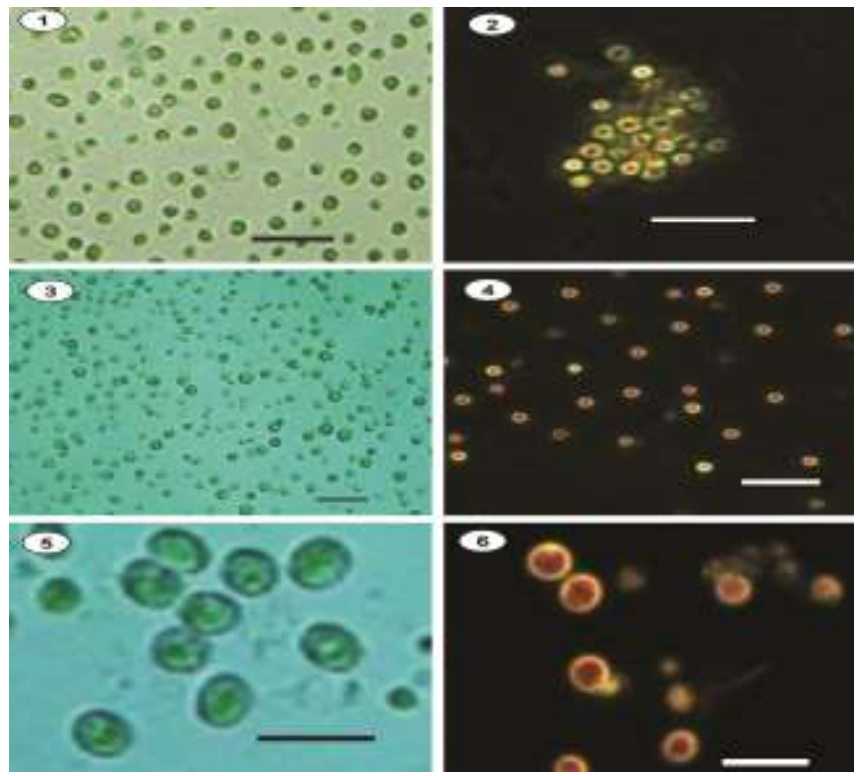

Fig 1: Comparative of study of microalgae under light microscope and inverted fluorescent microscope. Light microscopic (1, 3, and 5) and fluorescent microscopic images with Nile red staining $(2,4$ and 6) of promising microalgal isolates. (1\&2) Chlorella sp. SBC17; (3\&4) Chlorella sp. SBC19; (5\&6) Chlorella sp. SBC18.

\section{Results and Discussion}

\section{Study the physico-chemical parameters from estuaries of Khambat region, Gujarat.}

Twenty four samples were collected from six different places comprising various estuary habitats e.g. temporary pool, ditch, main stream of river, estuary region of sea, sand surface of river bed etc. from the gulf of Khambhat, Gujarat on seasonal basis. Temperature and $\mathrm{pH}$ was measured using portable thermometer and $\mathrm{pH}$ meter at each site respectively. Limnological analyses of sample of cations and anions like (calcium, chloride, fluoride, magnesium, sulphate and total hardness as $\mathrm{CaCO}_{3}$ ) were done by Vaibhav analytical services, Ahmedabad using established protocols. The values from various sites have been listed in Table 1. 
Table 1: Physico-chemical parameters from different estuaries of Khambhat region

\begin{tabular}{lllllll}
\hline Parameters & Site 1 & Site 2 & Site 3 & Site 4 & Site 5 & Site 6 \\
\hline $\mathrm{pH}$ & 8.06 & 8.04 & 8.57 & 8.39 & 8.49 & 8.55 \\
Temperature $\left({ }^{\circ} \mathrm{C}\right)$ & 28.00 & 29.00 & 31.00 & 30.00 & 29.00 & 28.5 \\
Conductivity $(\mathrm{ms} / \mathrm{cm})$ & 11.46 & 10.75 & 2.14 & 2.19 & 0.64 & 0.65 \\
TDS $(\mathrm{ppm})$ & 7.33 & 6.88 & 1.37 & 1.40 & 413.00 & 418.00 \\
Salinity $(\mathrm{mg} / \mathrm{l})$ & 58.49 & 59.67 & 798.00 & 232.00 & 38.00 & 49.00 \\
Calcium $(\mathrm{mg} / \mathrm{l})$ & 380.00 & 360.00 & 21.00 & 19.00 & 28.00 & 25.00 \\
Chloride $(\mathrm{mg} / \mathrm{l})$ & 3619.00 & 3541.00 & 484.00 & 141.00 & 23.00 \\
Fluoride $(\mathrm{ppm} / \mathrm{l})$ & 8.00 & 6.00 & 2.00 & 1.50 & 1.00 \\
Magnesium (mg/l) & 1227.00 & 1336.00 & 41.00 & 41.00 & 16.00 & 1.00 \\
Sulphate $(\mathrm{mg} / \mathrm{l})$ & 2832.00 & 2976.00 & 80.00 & 84.00 & ND & ND \\
Total hardness as CaCO3 (mg/l) & 60000.00 & 6400.00 & 220.00 & 216.00 & 140.00 & 130.00 \\
Nitrogen $(\mathrm{mg} / \mathrm{l})$ & $\mathrm{ND}$ & $\mathrm{ND}$ & $\mathrm{ND}$ & 23.00 & ND & ND \\
Phosphorus (mg/l) & 4.19 & 4.28 & 8.78 & 9.34 & 8.91 & 9.12 \\
Organic Carbon (mg/l) & 70.00 & 39.00 & $\mathrm{ND}$ & $\mathrm{ND}$ & ND & ND \\
\hline
\end{tabular}

Site 1. Kavi Kambhoi 2. Kavi Kambhoi location-2 Site 3. Bhadbhut Site 4.Bhadbhut location 2, Site 5. Jhadeshwer Site 6. Jhadeshwer location -2. ND: Not detected

Table 2: List of unialgal cultures isolated from different estuarine sites of Khambhat, Gujarat

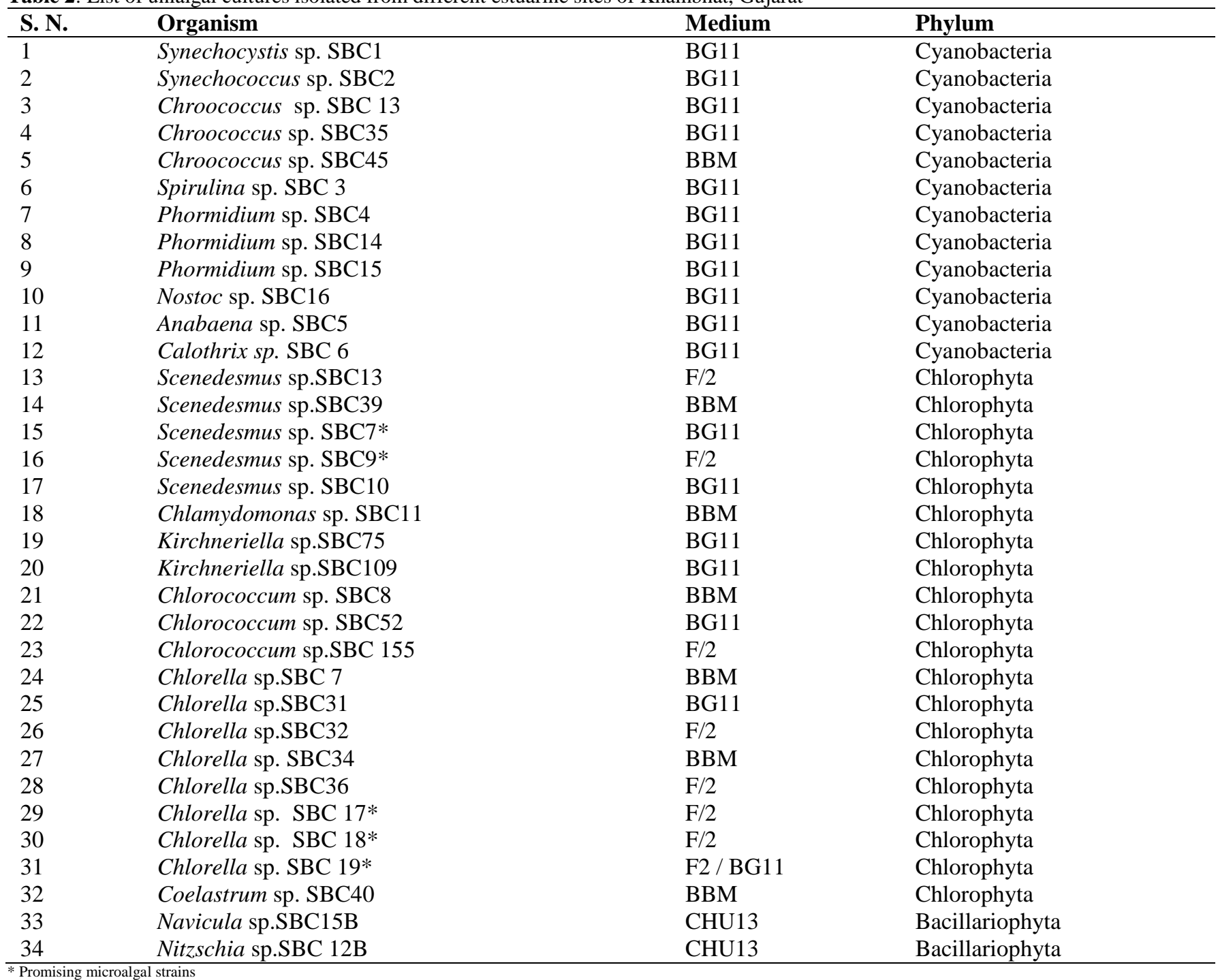




\section{Determination of acetyl CoA carboxylase (ACCase) activities from promising strains}

The fatty acid synthesis is the conversion of acetyl CoA to malonyl CoA, catalyzed by acetyl CoA carboxylase (ACCase). In the chloroplast, photosynthesis provides an endogenous source of acetyl CoA, and more than one pathway may contribute to maintaining the acetyl CoA pool. Two in house isolates i.e. SBC19 and SBC 17 showed highest acetyl CoA carboxylase (ACCase) of $55.2(\mathrm{U} / \mathrm{ml})$ and $51.2(\mathrm{U} / \mathrm{ml})$ with $0.375 \mathrm{~g} / \mathrm{l}$ nitrogen concentration in 24 days respectively. But when algae strains were grown in 1.5 $\mathrm{g} / \mathrm{L} \quad\left(\mathrm{NaNO}_{3}\right)$ medium the acetyl $\mathrm{CoA}$ carboxylase decreased in terms of $\mathrm{U} / \mathrm{ml}$ in 24 days. These results were points out that as the specific nitrate concentration $(0.375$ $\mathrm{g} / \mathrm{l})$ in the medium acetyl CoA carboxylase enzyme are increased (Table.3). The enzyme dependent was due to level of stress environment and also varies the enzyme accumulated in the cells. The present study suggested that nitrogen starvation with acetyl CoA carboxylase path way is the effective approach to enhance lipid for biofuel production.

\section{Effect of Nitrogen source on microalgae growth and determination of biomass, lipid content from potential strains}

The above five strains were selected for nitrogen starvation experiment. $\mathrm{NaNO}_{3}$ was used as nitrogen source in the respective medium $\left(1.5,0.75,0.375, \mathrm{~g}^{-1}\right)$. The following table shows the effect of nitrogen stress condition. The results indicated that as the nitrogen concentration in the medium decreased, biomass production decreased (Table. 4) and increased the lipid content. The present study indicated that nitrogen starvation is the effective approach to enhance algal lipid content. Two in house isolates i.e. SBC19 and SBC 17 showed highest acetyl CoA carboxylase (ACCase) of $55.2(\mathrm{U} / \mathrm{ml})$ and $51.2(\mathrm{U} / \mathrm{ml})$ with $0.375 \mathrm{~g} \mathrm{l}^{-1}$ nitrogen concentration in 24 days. These strains were highest biomass and lipid content in respectively

Table 3: Show various strains with acetyl CoA carboxylase enzyme activity under different nitrogen starved conditions.

\begin{tabular}{|c|c|c|c|c|}
\hline $\begin{array}{l}\text { Strains } \\
\text { No. }\end{array}$ & $\begin{array}{l}\text { Acetyl CoA Carboxylase } \\
\text { (U/ml) } \\
\text { (No - NaNO3) }\end{array}$ & $\begin{array}{l}\text { Acetyl CoA } \\
\text { Carboxylase } \\
(\text { U/ml) } \\
(0.375 \text { g/l- } \\
\text { NaNO3) }\end{array}$ & $\begin{array}{l}\text { Acetyl CoA Carboxylase } \\
\text { (U/ml) } \\
(0.75 g / l-N a N O 3)\end{array}$ & $\begin{array}{l}\text { Acetyl CoA Carboxylase } \\
\text { (U/ml) } \\
(1.5 \mathrm{~g} / \mathrm{l}-\mathrm{NaNO3})\end{array}$ \\
\hline SBC 7 & 24.2 & 22.8 & 27.2 & 12.8 \\
\hline SBC 9 & 22.8 & 28.4 & 24.0 & 20.0 \\
\hline SBC 17 & 43.6 & 51.2 & 47.2 & 48.0 \\
\hline SBC 18 & 38.2 & 43.2 & 42.0 & 40.0 \\
\hline SBC 19 & 42.8 & 55.2 & 45.0 & 42.2 \\
\hline
\end{tabular}

Table 4: Effect of chemical stress $\left(\mathrm{NaNO}_{3}\right)$ on microalgal biomass and lipid production.

\begin{tabular}{|c|c|c|c|c|}
\hline Sr. No. & Strain No. & $\begin{array}{l}\text { Nitrogen starvation } \\
\left(\mathrm{g} \mathrm{l}^{-1} \mathrm{NaNO}_{3}\right)\end{array}$ & Biomass production $\left(\mathrm{g} \mathrm{l}^{-1}\right)$ & $\begin{array}{l}\text { Total lipid in } \\
\text { dry weight }(\%)\end{array}$ \\
\hline \multirow{3}{*}{1} & \multirow{3}{*}{ SBC 7} & 1.500 & 1.2 & 26 \\
\hline & & 0.750 & 0.9 & 32 \\
\hline & & 0.375 & 0.7 & 40 \\
\hline \multirow{3}{*}{2} & \multirow{3}{*}{ SBC 9} & 1.500 & 2.2 & 30 \\
\hline & & 0.750 & 1.9 & 38 \\
\hline & & 0.375 & 1.6 & 42 \\
\hline \multirow{3}{*}{3} & \multirow{3}{*}{ SBC 17} & 1.500 & 2.7 & 28 \\
\hline & & 0.750 & 2.5 & 42 \\
\hline & & 0.375 & 2.1 & 48 \\
\hline \multirow{3}{*}{4} & \multirow{3}{*}{ SBC 18} & 1.500 & 2.3 & 28 \\
\hline & & 0.750 & 1.9 & 42 \\
\hline & & 0.375 & 1.6 & 47 \\
\hline \multirow{3}{*}{5} & \multirow{3}{*}{ SBC 19} & 1.500 & 2.4 & 28 \\
\hline & & 0.750 & 1.9 & 48 \\
\hline & & 0.375 & 1.6 & 52 \\
\hline
\end{tabular}




\section{Conclusions}

It can be conclude that five promising microalgal strains (SBC 7, SBC 9, SBC 17, SBC 18 and SBC 19) have been selected. Two of the isolates i.e. SBC19 and SBC 17 have given very high biomass production of 2.4 and $2.7 \mathrm{~g} / \mathrm{l}$, respectively. Their lipid accumulation was found significantly enhanced by more than $50 \%$ on dry mass basis under nitrogen starvation. The five promising microalgae species will be used for further research and development work for biofuel production

\section{Acknowledgements}

We thank Indian council of Agricultural Research (ICAR) for financial assistance and Dr. M. Shyam, Director, Sardar Patel Renewable Energy Institute for providing laboratory facilities.

\section{References}

Chiara B, Inna Khozin G, Sammy B, Avigad V and Zvi C (2002) Lipid and fatty acid composition of the green oleaginous alga Pariotochloris incises the richest plant source of arachidonic acid. Phytochemistry 60(5):497-503.

Chisti Y (2007) Biodiesel from microalgae. Biotechnol. Adv. 25: 294-306.

Chu SP (1942) The influence of the mineral composition of the medium on the growth of planktonic algae. Part I. methods and culture media. J.Ecol.,30: 284-325.

Desikachary TV (1959) Cyanophyta. ICAR Monographs on Algae. ICAR New Delhi. 1- 686.

Guillard RRLand Ryther JH (1962) Studies of marine planktonic diatoms. I. Cyclotella nana Hustedt and Detonula confervacea Cleve. Can. J. Microbiol. 8:229-239.
Harun R, Singh M, Forde GM and Danquah MK (2010) Bioprocess engineering of microalgae to produce a variety of consumer products. Renew. Sust. Energ. Rev. 14 : 1037 1047.

Himansu Sekhar P, Manoranjan NB, Bikram K, Parida JJ, Sukumar B, Sandeep P, Prasanna Kumar P and Lala Bihari S (2011) Survey and Documentation of Brackish Water Algal Diversity from East Coast Region of Odisha, India. World Environment 1: 20-23.

Iyengar MOP and Desikachary TV (1981) Volvocales. ICAR, New Delhi, 1- 532.

Khan SA, Rashmi, Hussain MZ, Prasad S and Banerjee UC (2009) Prospects of biodiesel production from microalgae in India. Renew. Sust. Energ. Rev. 13:2361-2372.

Mata TM, Martins AA and Caetano NS (2010) Microalgae for biodiesel production and other applications: a review. Renew. Sust. Energ. Rev. 14: 217-232.

Phillipose MT (1967) Chlorococcales ICAR, New Delhi. 1-356.

Rippka RJ, Deruelles JB, Waterbury M, Herdman RY and Stanier (1979) Generic assignments, strain histories and properties of pure cultures of cyanobacteria. Journal of Geneneral Microbiology, 111: 1-61.

Starr RC and Zeikus JA (1993) UTEX - The culture collection of algae at the University of Texas at Austin. J Phycol Suppl 29: $1-106$.

Willis L, Omar WS, Sambanthamurthi R and Sinskey A (2008) Non- Radioactive Assay for Acetyl- CoA Carboxylase Activity. Journal of Oil Palm Research Special Issue on Malaysia-MIT Biotechnology Partnership Programme: Oil Palm Metabolic Engineering, 30-36 